\title{
Immobilization of Glucanobacter Xylinum Onto Natural Polymers to Enhance the Bacterial Cellulose Productivity
}

Mohamed Abdelraof ( $\sim$ abdelraof87@gmail.com )

National Research Center Inc

Houssni El-Saied

Professor in Paper and Cellulose chemistry

Mohamed S. Hasanin

Cellulose and Paper Department, National Research Centre, 12622, Dokki, Cairo, Egypt

\section{Research}

Keywords: Bacterial cellulose, Sugar Cane Bagasse, Immobilization, Optimization, Reusability

Posted Date: December 1st, 2020

DOI: https://doi.org/10.21203/rs.3.rs-113669/v1

License: (1) This work is licensed under a Creative Commons Attribution 4.0 International License.

Read Full License

Version of Record: A version of this preprint was published at Waste and Biomass Valorization on January 19th, 2022. See the published version at https://doi.org/10.1007/s12649-021-01666-w. 
3 Mohamed Abdelraof ${ }^{1^{*}}$, Houssni EI -Saied ${ }^{2}$ and Mohamed S. Hasanin ${ }^{2 *}$

$4{ }^{1}$ Microbial Chemistry Department, National Research Centre, 12622, Dokki, Cairo,

5 Egypt.

$6 \quad{ }^{2}$ Cellulose and Paper Department, National Research Centre, 12622, Dokki, Cairo,

7 Egypt.

$8 *$ Corresponding authors.

9 E-mail addresses: abdelraof87@gmail.com (M. Abdelraof), sido_sci@yahoo.com (M.

10 Hasanin).

11 Abstract

Bacterial cellulose (BC) has profound applications in different sectors of biotechnology due to its unique properties preferring it about plant cellulose. Although this polymer is extremely important in various applications, many problems still hinder the sustainable production in terms of increasing productivity and low-cost production. In order to overcome these problems, this study will focuses on the continuous production of cellulose using immobilized Glucanobacter xylinum cells onto Sugar Cane Bagasse (SCB) and Ca-alginate beads. Comparatively, adsorption of Glucanobacter xylinum cells to the cavum of stalk cells of SCB could be efficiently stable while, entrapment of cells onto Ca-alginate has drawback observed by the rapid disruption and instability of the beads in the Potato Peel Waste (PPW) culture medium. Our findings demonstrate that a combination between alternative low-cost medium with continuous production mode by immobilization onto inexpensive natural polymer can promote a sustainable bioprocess and reduction the production cost.

Key words: Bacterial cellulose, Sugar Cane Bagasse, Immobilization, Optimization, Reusability. 
Cellulose is one of important biopolymer on the earth. Although many bioapplications depending on cellulose as raw material (Hasanin et al., 2018, Abdelraof et al., 2020b, Hasanin and Al Kiey, 2020), but some bio-fields cannot use the traditional cellulose (Abdelraof et al., 2019a, Abdelraof et al., 2019b). Traditional cellulose produced mainly from tree fibers or wood pulping followed by many chemical process reactions to produce pure cellulose with some traces of contaminants(Hasanin et al., 2018, Hasanin et al., 2019). On the other hand, the bacterial cellulose $(\mathrm{BC})$ can be offered pure type of cellulose use in all bio-fields without any restrictions(Abdelraof et al., 2019a, Abdelraof et al., 2019b). Moreover, the $\mathrm{BC}$ produced overall via green methods without any environmental hazardous. However, the production of $\mathrm{BC}$ has many problems must be overcome to involved into the industrial levels e.g. contact performance of microorganism with media, productivity value, features of produced $\mathrm{BC}$, economics factors and production strategy applicability(Watanabe et al., 1998). The specific features of BC can be summarized as high biocompatibility, biodegradable, mouldability, easy handling, low equipment's required and free from contaminated ions(Kowalska-Ludwicka et al., 2013). The $\mathrm{BC}$ can be considering as the new generation material in many applications especially medical, pharmaceutical, biomaterials industries. Furthermore, according to the high safety profile of $\mathrm{BC}$ it can be considered as edible biopolymer with platform of bio-field uses. However, the biggest drawback of $\mathrm{BC}$ production is the productivity manipulation(Watanabe et al., 1998, Chen and Huang, 2015). Since the production scheme can be controlled the productivity as well as characterization of BC. However, the BC production suffers from many inhibitory effects such as a high operating cost, rapid consumption of the substrate, rapid alteration in cultural $\mathrm{pH}$, and a low BC productivity(Bilgi et al., 2016, Abdelraof et al., 2019a). The inevitability of $\mathrm{BC}$ production from agro-industrial natural waste has been recommended by many authors because of its economic and environmental viability(Abdelraof et al., 2019a). The potentiality to use the various wastes resulting from the food-processing in the hydrolysate form is effectively attractive for scalable BC biosynthesis (Hong et al., 2012, Chen et al., 2013, Cheng et al., 2017). Among the several agricultural waste advised by many studies for bacterial cellulose production, Potato peel wastes (PPW) have been shown to be practical, economical and environmental friendly (Abdelraof et al., 2019a). Traditional industrial BC production is generally performed using a free-cell system. The free-cell systemhas several 
limitations, such as a high operating cost, rapid consumption of the substrate, low in pH stability, and a low BC productivity. Several approaches have been suggested to improve BC production efficiency, involving supplementation of the cultural medium with some regulators such as ethanol or organic acids in order to inhibit the accumulation of the basic metabolic byproduct (gluconic acid) and at the same time stimulate the synthesis of substances necessary for the cell stabilization( $\mathrm{Lu}$ et al., 2016, Stepanov and Efremenko, 2018). However, these additivesare not suitable, due to metabolic process in the bacterial cellulose cells comprised of series of enzymes which are extensively active in the presence of cyclic diguanidine monophosphate (cdi-GMP). This molecule playing an important role in the pathway of $\mathrm{BC}$ biosynthesis, and an incorporation of these substances areaccompanied with activation of phosphodiesterases in the cells which catalyzing degradation of c-di-GMP which in turn caused an inhibitory effect on BC biosynthesis(Morgan et al., 2014). Therefore, to improve the BC yield it should be foster the key molecule c-di-GMP in the metabolic process of the cells. As discussed by(Srivastava and Waters, 2012, Stepanov and Efremenko, 2018) c-di-GMP is a major metabolic molecule called as "quorum factor," since the highly cells concentrations was correlated with quorum state. In this state the BC production was increased by the expression of "silent genes" and the synthesis of exopolysaccharides with a simultaneous decrease in the rate of active cell growth. Therefore, cells that produce BC should be stimulated to come into a quorum state, which the cells become genetically programmed to their increased population. The cell-immobilization system in case of BC producers could allow obtaining highly concentrated populations of cells since BC synthesis would be regulated by a quorum sensing phenomena as described before.Interestingly, the immobilization of $\mathrm{BC}$ cells opens a way to improve cell stabilization and thus led to increase BC productivity. Comparatively, the immobilized cells have various benefits more than free cells in the production process, such as increased the cell population density, improved operational stability by protection the cells from the adverse environmental conditions, prevent the inhibition effect of the end product, enhanced the cell resistance to high substrate concentration via diffusional constrains and afford microbial cells to reusability it in several bioprocess which reduce the production costs(Nuanpeng et al., 2018, Stepanov and Efremenko, 2018). Unfortunately, in spite of the overall advantages of immobilization process the current reports concerning the 
production of $\mathrm{BC}$ by immobilized-cell system are very rare. In this regard, PVA cryogel was used for employing Komagataeibacterxylinum cells in an immobilized system to increase the biosynthesis of BC (Stepanov and Efremenko, 2018). Acetobacter xylinum ATCC 700178 cells was successfully immobilized on a plastic composite support (PCS) to improve the BC production on the basis of polypropylene (Cheng et al., 2009). However, the severe masstransfers restrictions, low mechanical strength, non-biodegradability and highly toxicity of these synthetic polymers displaying a big problem in the operational stability of the immobilized cells (Basak et al., 2014, Nuanpeng et al., 2018). Therefore, we tried to finding out a renewable, easily prepared, inexpensive, biodegradable, non-toxic, and available naturally carrier. Limitations correlated with the use of synthetic polymers can be avoided by the use of Sugarcane bagasse (SCB)as immobilization carrier. Sugarcane bagasse (SCB) considered as a lignocellulosic material derived from the processing of sugarcanewhich naturally in abundance, easy to use, cheaper and non-toxic(Yu et al., 2007, Basak et al., 2014, Liu et al., 2015). Selectivity of SCB in several studies due to its having various unique characteristics such as chemical stability, highly porous, high surface area, remained unchanged under different $\mathrm{pH}$ and temperature values (Basak et al., 2014). Besides, alginate beads proved to be an efficient support for entrapment ofmicrobial cells due to their biodegradability, low toxicity, prepared easily, and low cost efficiency (Banerjee and Ghoshal, 2011). On the other hand, bioprocess production frequently needed to optimize its nutritional and cultural conditions by statistical experimental designs. The important of these designs are attributed to its reduction in time consumption and a reduction in operating costs due to fewer experimental units (Abdelraof et al., 2020a). The most common statistical experimental designs, Plackett-Burman design (PBD) have been generally established for the optimization of the multiple variables in the culture media, and process conditions. These techniques were efficiently utilized to explain the interaction betweenindependent variables and developing a mathematical model that exactly describes the general process. To the best of our knowledge, there are no studies have yet been established on the statistical optimization of BC production using immobilized-cell system despite its high industrial applications. Therefore, we investigated the enhancement of bacterial cellulose production by immobilized $G$. xylinum ATCC 10245 by using statistical analysis in PPW medium via continuous production of BC. The comparative study of fibrous SCB and nonfibrous alginate as an immobilization carrier was carried out as well as the BCs produced from both free 
and immobilized cells were also characterized. Moreover, studies have been done to perform reuse experiments with the immobilized cells and storage stability.

\section{Materials and Methods}

\subsection{Materials}

Bagasse fibers were delivered from integrated sugar industrial company, Quena, Egypt. Na-alginate purchase from molekula (U.K), Potato peel waste (PPW) was resulting from potatoes processing, and collected from the disposal of free markets. The bright PPW without disease symptoms were selected then washed thoroughly with distilled water. All reagents, solvents, medium and its components used in this study were of analytical grade.

\subsection{Methods}

\subsubsection{Microorganism and culture condition}

The cellulose producing bacterium Gluconacetobacter xylinum ATCC 10245 used in this study was donated from the American Type Culture Collection (ATCC), Manassas, VA, USA. The bacterial strain was maintained by bimonthly transfer to fresh HS medium (glucose, $1 \%$; peptone, $0.5 \%$; yeast extract, $0.5 \% ; \mathrm{K}_{2} \mathrm{HPO}_{4}, 0.27 \%$; $\mathrm{MgSO}_{4}, 0.05 \%$; citric acid, $0.115 \%$ ); and stored at $4{ }^{\circ} \mathrm{C}$, after incubation at $30^{\circ} \mathrm{C}$. Preculture of the strain was carried out at $30{ }^{\circ} \mathrm{C}$ on a rotary shaker at $180 \mathrm{rpm}$ for 24 h.

\subsubsection{Adsorption of bacterial cells in SCB particles}

Sugar cane bagasse (SCB) was obtained from a sugarcane juice local market in Cairo, Egypt,after the skin and the outside fiber were removed; SCB was chopped into small particles using a food processor. The chopped SCB was then dried, and approximately $50 \mathrm{~mL}$ moisture was vaporized from $100 \mathrm{~g}$ raw SCB. Bagasse which was obtained after drying was sieved to remove fine and larger particles. The pieces of SCB were sieved to obtain particle sizes of $1 \mathrm{~mm} \times 1 \mathrm{~mm} \times 1 \mathrm{~mm}, 2.5 \mathrm{~mm} \times 2.5$ $\mathrm{mm} \times 2.5 \mathrm{~mm}, 5 \mathrm{~mm} \times 5 \mathrm{~mm} \times 5 \mathrm{~mm}$, and $10 \mathrm{~mm} \times 10 \mathrm{~mm} \times 10 \mathrm{~mm}$. The crushed and classified SCB was washed several times with sterilized distilled water and dried at $105^{\circ} \mathrm{C}$. This untreated material was sterilized by autoclave and then used as support for cell immobilization. Cells were immobilized in situ in the fermentation flasks by natural adsorption onto the untreated SCB according to the method described by $(\mathrm{Yu}$ et al., 2007). $5 \mathrm{~g}$ SCB with different sizes was autoclaved and then mixed with $50 \mathrm{ml}$ 
fresh pre-culture HS medium which was previously inoculated with $10 \mathrm{ml}$ cell suspension $\left(1.9 \times 10^{9} \mathrm{cfu} / \mathrm{ml}\right) .24 \mathrm{~h}$ later, the SCB prepared above was combined with $50 \mathrm{ml}$ Potato Peel Waste hydrolysate medium and then replaced by a fresh $50 \mathrm{ml}$ medium after 7 days.

\subsubsection{Entrapment of bacterial cells in alginate beads}

The cellulose-producing bacterium (Gluconacetobacter xylinum ATCC 10245) was harvested after $24 \mathrm{~h}$ of growth (early stationary phase preculture) from $250 \mathrm{ml}$ of HS culture medium. The cell pellet $(0.8 \mathrm{~g}$ wet weight containing $4 \times 10^{9} \mathrm{CFU}$ ) was obtained by centrifugation at $5000 \mathrm{rpm}$ for $10 \mathrm{~min}$ and subsequently re-suspended in $10 \mathrm{ml}$ phosphate buffered saline (PBS). A stock of 2-5\% (w/v) sodium alginate was prepared and autoclaved at $121^{\circ} \mathrm{C}$ for $15 \mathrm{~min}$. Tenmilliliters of bacterial cell suspension $\left(4 \times 10^{9} \mathrm{CFU}\right)$ was added to $50 \mathrm{ml}$ of sterilized alginate solution and mixed by stirring on a magnetic stirrer. This alginate cell mixture was extruded drop by drop into a cold sterile $0.1 \mathrm{M}$ calcium chloride solution $\left(\mathrm{CaCl}_{2}\right)$. The drops of alginate cell solution were gelled to form a uniform and defined-sized sphere upon contact with $\mathrm{CaCl}_{2}$ solution. The immobilized beads were left in $0.2 \mathrm{M} \mathrm{CaCl}_{2}$ solution at room temperature for $1 \mathrm{~h}$ to harden and complete the gel formation. The beads were then rinsed with sterilized bi-distilled water several times to remove residual $\mathrm{CaCl}_{2}$. Blank alginate beads without bacterial cells were also prepared in the same way for control experiments(Banerjee and Ghoshal, 2011). $5 \mathrm{~g}$ of wet alginate beads containing entrapped cells were added to PPW culture medium and then replaced by a fresh $50 \mathrm{ml}$ medium after 7 days.

\subsubsection{Analytical procedures}

At the end of cultivation period, the fermentation broth and $\mathrm{BC}$ were separated by centrifugation at $10,000 \mathrm{~g}$ for $10 \mathrm{~min}$ to separate cellulose from the supernatant. The produced BC is collected, rinses in distilled water, and immerses in $\mathrm{NaOH} 0.1 \mathrm{~N}$ at $60{ }^{\circ} \mathrm{C}$ for $90 \mathrm{~min}$ to remove attached cells and impurities. Later, pellicles are rinsed in methanol solution and then wash with the deionized water and dry at $60{ }^{\circ} \mathrm{C}$ for $24 \mathrm{~h}$ to evaluate the $\mathrm{BC}$ yield concentration in $\mathrm{g} \mathrm{L}^{-1}$ (mass (g) of BC/volume (L) of culture medium)(Abdelraof et al., 2019a). The carrier matrix (SCB particles and alginate beads) and the immobilized cells were examined using a scanning electron microscope. The samples for electron microscopy were prepared according to the method described by ( $\mathrm{Yu}$ et al., 2007). In all BC production experiments, the reducing sugar concentration of in the PPW culture medium was 
measured by DNS according to the procedure reported in our previous work (Miller, 1959). As well as, cell retention ( $\mathrm{Cr}, \mathrm{CFU} \mathrm{\textrm {g } ^ { - 1 }}$ ) onto the SCB particle and alginate beads were measured as the ratio of total number of CFU immobilized onto the carrier to the carrier mass (g). Log CFU was determined as adapted by(Abdelraof et al., 2019a).

The immobilization efficiency (Yi, \%) was calculated as follows:

$$
Y i=\frac{\mathrm{Ci}}{\mathrm{Ct}} x 100
$$

Where $\mathrm{Ci}$ is the concentration of immobilized cell calculated as the ratio of total number of CFU immobilized onto the SCB carrier to the total medium volume.

$\mathrm{Ct}$ is the ratio of concentration of total cell in the flask, i.e., suspended plus immobilized, to the medium volume) (Santos et al., 2008).

\subsubsection{Release of adsorbed and entrapped cells}

The carrier containing BC cells were released by citrate-phosphate buffer $(\mathrm{pH}=6.0,1 \%)$ reported by(Basak et al., 2014). One gram of the beads or particles was transferred to $9 \mathrm{~mL}$ buffer. The solution was stirred on a shaker for $15 \mathrm{~min}$ vigorously until bacteria released from matrix completely. The counts (Log CFU/g) were determined by plating on HS agar plates and incubating for $48 \mathrm{~h}$ at $37^{\circ} \mathrm{C}$. The free bacteria were treated similarly.

\subsubsection{Statistical optimization of BC production by immobilized Glucanobacter} xylinum

The production and statistical optimization of $\mathrm{BC}$ using Glucanobacter xylinum immobilized onto SCB carrier has been performed in four sequential steps; Plackett-Burman experimental design, doing the experiment, data analysis and validation of the results (Abdelraof et al., 2019c). Prior to statistical modeling, the different factors were tested for the optimum maximum and minimum levels of study based on One-factor-at-a-time method. Initially, the cultural conditions before optimization were evaluated for $\mathrm{BC}$ production, and then were considered for further optimization studies. Modeling of BC production by the immobilized Glucanobacter xylinum has been conducted using Plackett-Burman factorial design (PBD) to select the major factors influencing BC production. Table (1) shows the PBD with seven numeric factors namely; Sugar concentration of the PPW hydrolysate, Medium volume ratio, Spore concentration in the carrier, $\mathrm{pH}$, Incubation time, Incubation 
temperature, and carrier quantity. The experimental design composed of 21 experimental trials; among these, one run was carried out at the center point values, while each remaining runs will conduct at 2-levels by combinations of upper ('high, +') and lower ('low, -') levels of all variables. In the PBD, two levels were used to determine whether the maximum production was obtained at lower or higher concentration of the variables by comparing them with the experimental results obtained from center point values

Experimental responses were measured by first order model by the following equation: $Y=\beta 0+\sum \beta i x i$

Where $\mathrm{Y}$ is the response for $\mathrm{BC}$ production, $\mathrm{B}_{o}$ is the model intercept and $\beta_{i}$ is the linear coefficient, and $x_{i}$ is the level of the independent variable. According to the Stat-Ease analysis, a first-order model could be obtained from the regression results of fractional factorial experiment. This model describes the interaction among factors and it is used to screen and evaluate important factors that influence the response. The main effect of each variable was determined according to the following equation:

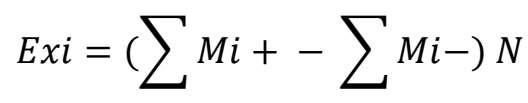

Where $E_{x i}$ is the variable main effect, $\Sigma M_{i_{+}}$is the summation of the response value at high level; $\Sigma M i^{-}$is the summation of the response value at low level, and $N$ is the number of experiments. For Plackett-Burman design and analysis of variance (ANOVA), Minitab 17-software (version 17.0.0) has been used.

Table 1: Plackett-Burman design

\begin{tabular}{|c|c|c|c|c|c|}
\hline Factor & Name & Units & Low & High & Mean \\
\hline $\mathrm{A}$ & Sugar conc. & $\%(\mathrm{w} / \mathrm{v})$ & 0.5 & 1.0 & 0.25 \\
\hline $\mathrm{B}$ & Medium volume ratio & $\mathrm{ml}$ & 20 & 50 & 3 \\
\hline $\mathrm{C}$ & Spore conc. & CFU/g & $5 \times 10^{7}$ & $8.5 / 10^{4}$ & 7 \\
\hline $\mathrm{D}$ & $\mathrm{pH}$ & Value & 6 & 9 & 3.5 \\
\hline $\mathrm{E}$ & Incubation time & Day & 4 & 7 & 2.5 \\
\hline $\mathrm{F}$ & Incubation temperature & ${ }^{\circ} \mathrm{C}$ & 25 & 37 & 2.3 \\
\hline $\mathrm{G}$ & Matrix quantity & $\%(\mathrm{w} / \mathrm{v})$ & 2 & 5 & 1.5 \\
\hline
\end{tabular}

\subsubsection{Reusability and storage stability of immobilized cells}

In order to study the reusability of the SCB immobilized cells, after every batch BC production, the whole SCB contents of the flasks were collected aseptically from the spent medium and washed three times with sterile bi-distilled water. Then, SCB particles were used again separately for BC production with fresh PPW medium 
under the same experimental conditions. This cycle was repeated for ten times to evaluate the BC production capacity of reused immobilized cells. For comparative purposes, fermentation with free cells in flasks without the immobilization matrix was also carried out under the same culture condition. Unless otherwise noted, all batch fermentations were duplicated and averaged data are reported. The operational stability of the immobilized system was determined by the following equation:

Operational efficiency $(\%)=\frac{\mathrm{Cx}}{\mathrm{C} 1} \times 100$

Where $\mathrm{C} 1$ is the $\mathrm{BC}$ yield produced in the first (1st) fermentation cycle and $\mathrm{Cx}$ is the BC yield produced in the (Xth) fermentation cycle.

To identify the efficiency of SCB in the immobilization process, the fermentation kinetics during BC production is measured (Abdelraof et al., 2019a). The efficiency of $\mathrm{BC}$ production is evaluated after 7 days of cultivation and the, substrate conversion ratio, $\mathrm{BC}$ production rate and $\mathrm{BC}$ production yield are calculated, respectively, as described by(Lin et al., 2014):

Substrate conversion ratio $\%=\frac{\mathrm{Si}-\mathrm{Sf}}{\mathrm{Si}} \times 100$

BC production rate $(\mathrm{g} / \mathrm{L} . \mathbf{h})=\frac{m B C}{V x t}$

BC production $(\%)=\frac{\mathrm{mBC} / \mathrm{V}}{\mathrm{Si}-\mathrm{Sf}}$

Where $\mathrm{Si}$ is the initial concentration of substrate $(\mathrm{g} / \mathrm{L})$ (i.e. corresponding to the reducing sugar content of the PPW culture medium), Sf is the final concentration $(\mathrm{g} / \mathrm{L}), \mathrm{mBC}$ is the amount of $\mathrm{BC}$ produced $(\mathrm{g}), \mathrm{V}$ is the reactional volume $(\mathrm{L})$ and $\mathrm{t}$ is time of reaction $(\mathrm{h})$.

On the other hand, the effect of storage on the BC production capability of the immobilized cells was also investigated. The SCB and alginate beads containing the adsorbed and entrapped cells were stored for varying periods (up to 60 days) at $4{ }^{\circ} \mathrm{C}$.

\subsubsection{Characterization of $\mathrm{BC}$ membranes}

Fourier transform infrared (FTIR) the structure change between different produced $\mathrm{BC}$ was studied by attenuated total reflectance Fourier transform infrared (ATRFTIR) spectroscopy (Spectrum Two IR Spectrometer - PerkinElmer, Inc., Shelton, USA). All spectra were obtained by 32 scans and $4 \mathrm{~cm}^{-1}$ resolution in wave numbers ranging from 4000 to $450 \mathrm{~cm}^{-1}$. 
X-ray diffraction (XRD) the crystalline structure of samples was characterized using $\mathrm{X}$-ray (XRD) diffractometer (Schimadzu 7000, Japan) operating with $\mathrm{Cu} \mathrm{K} \alpha$ radiation $(\lambda=0.154060 \mathrm{~nm})$ generated at $30 \mathrm{kV}$ and $30 \mathrm{~mA}$ with scanning rate of $4^{\circ} \mathrm{min}-1$ for $2 \theta$ values between 10 and 80 degrees.

Scan electron microscope (SEM) the micrographs of the prepared samples were analyzed by scanning electron microscopy (SEM, Quanta FEG 250, FEI). To prepare the SEM sample, a thin layer of Au was coated onto the sample by sputtering coating device.

\section{Results and Discussion}

\subsection{Immobilization efficiency onto SCB particles and alginate beads:}

Immobilization of Glucanobacter xylinum cells onto fibrous and non-fibrous carriers could be an interesting technology to develop an efficient, low-cost and continuous process for cellulose productivity. In our previous report, Potato Peel waste-nitric acid hydrolysate culture medium was proved to be an excellent alternative medium for $\mathrm{BC}$ production and that due to its having high buffering capacity(Abdelraof et al., 2019a). Therefore, in order to increase the efficiency of cellulose production, immobilization of bacterial cells was carried out onto SCB (adsorption method) and alginate beads (entrapment method) in comparison with free cells under the same culture condition. Firstly, the immobilization efficiency of bacterial cells onto SCB particles and alginate beads were confirmed using scanning electron microscope (SEM) compared with the non-inoculated matrices (Fig. 1). As shown in (Fig. 1A, B), the bacterial cells were success attached in the alveolate of the stalk cells of the SCB definitely, and high cell concentration was observed. Electrostatic forces or covalent bonding between bacterial cells and carrier surface of SCB could be discussed the good bacterial cell adherence in the alveolate of the stalk cells(Santos et al., 2008, Basak et al., 2014). Another reason that clearly indicated to natural adsorption obtained due to the large surface area of the SCB structure, which could provided an easily attached and grow of the bacterial cells within the porous stalk cells which in turn increased and enhanced the biomass concentration. This ideally surface area contributing to the stability of the microenvironment for cell metabolism by greatly increasing the adherence of the bacterial cells (Basak et al., 2014). On the other hand, alginate beads were also analyzed by SEM microscopy before and after bacterial cells inoculation. Scanning electron micrographs confirmed 
the effective immobilization of Glucanobacter xylinum into alginate beads. Alginateentrapped bacterial cells were visually evaluated on the bead surface as seen in (Fig. 1C, D), since bacterial cells were restricted into the inner surface of the alginate beads via the entrapment process(Moreno Rivas et al., 2019). In this way, the immobilization efficiency (Yi) and bacterial cell retention $(\mathrm{Cr})$ by the carrier was measured up to $24 \mathrm{~h}$. As shown from (Fig. 1E, F), SCB particles demonstrated increasing in the immobilization efficiency and bacterial cell retention with maximum values of $90.6 \% \pm 2.8$ and $8.2 \pm 0.12 \mathrm{Log}$ CFU/g SCB respectively after $16 \mathrm{~h}$. and then decreased notably. In contrast, as evident from alginate beads results, the high immobilization efficiency and bacterial cell retention obtained after $4 \mathrm{~h}$. with $82.6 \%$ \pm 1.4 and $6.5 \pm 0.08 \mathrm{Log} \mathrm{CFU} / \mathrm{g}$ alginate beads and then decreased slightly. Obviously, this high immobilization efficiency of SCB more than alginate beads can be attributed to the large amount of vacuous and porous stalk cells which might be responsible for maximum cell adsorption (Yu et al., 2007, Basak et al., 2014). Additionally, the retention of bacterial cells could be more coherent in alginate beads than SCB particles and that may be due to the nature of entrapment method which protects the cells from leaking into the environment better than the adsorption method(Dzionek et al., 2016).
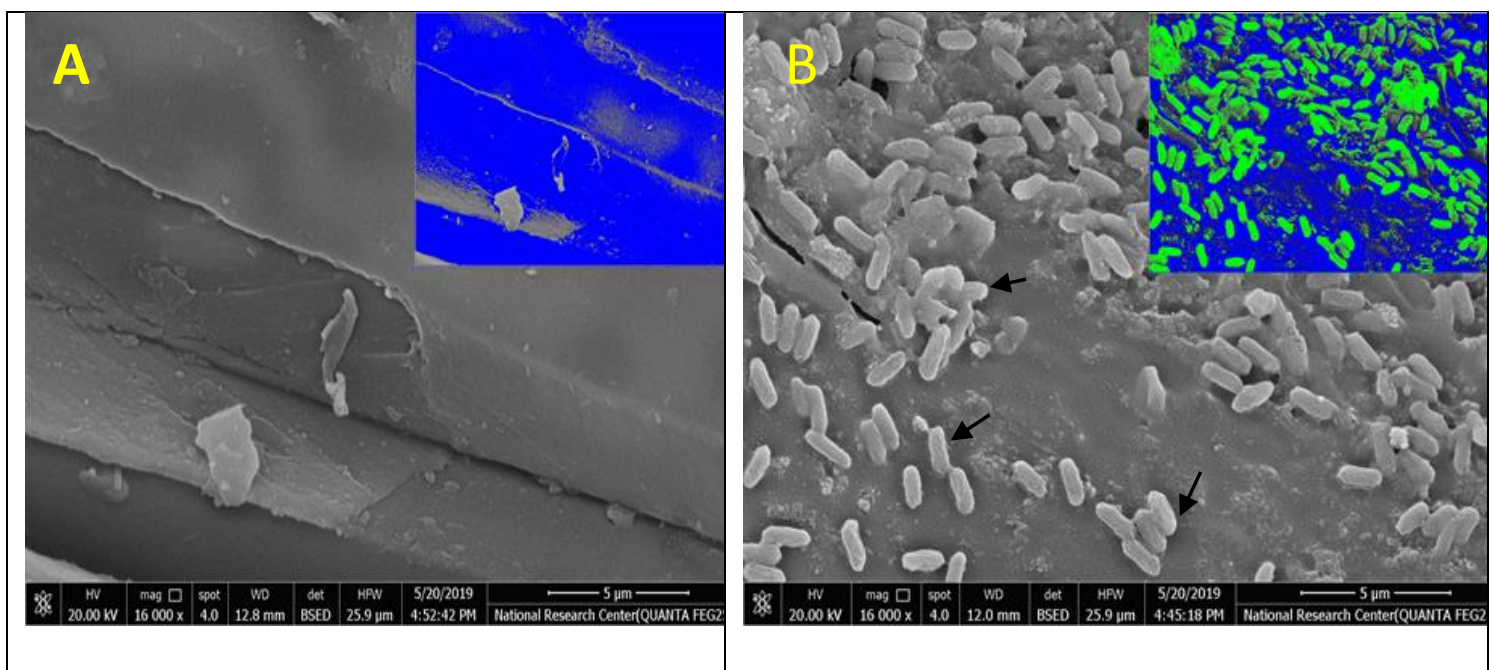


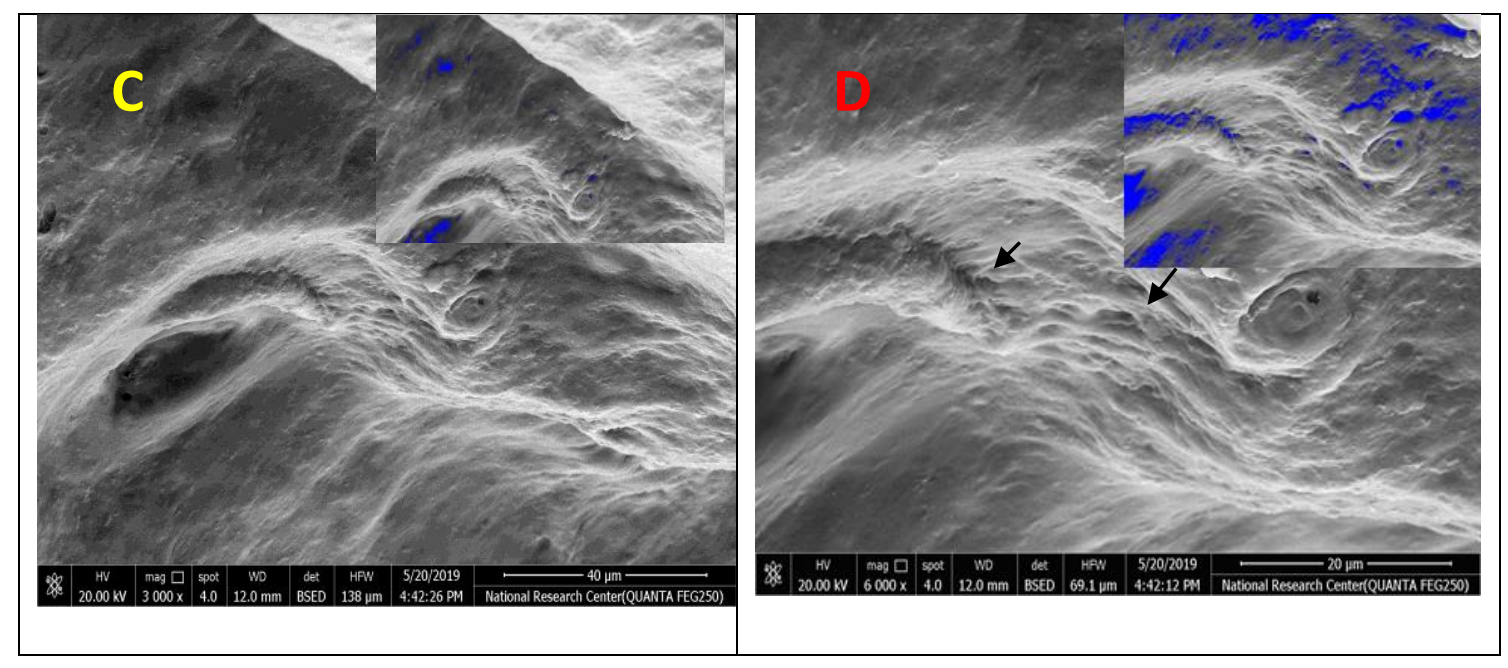

341

342

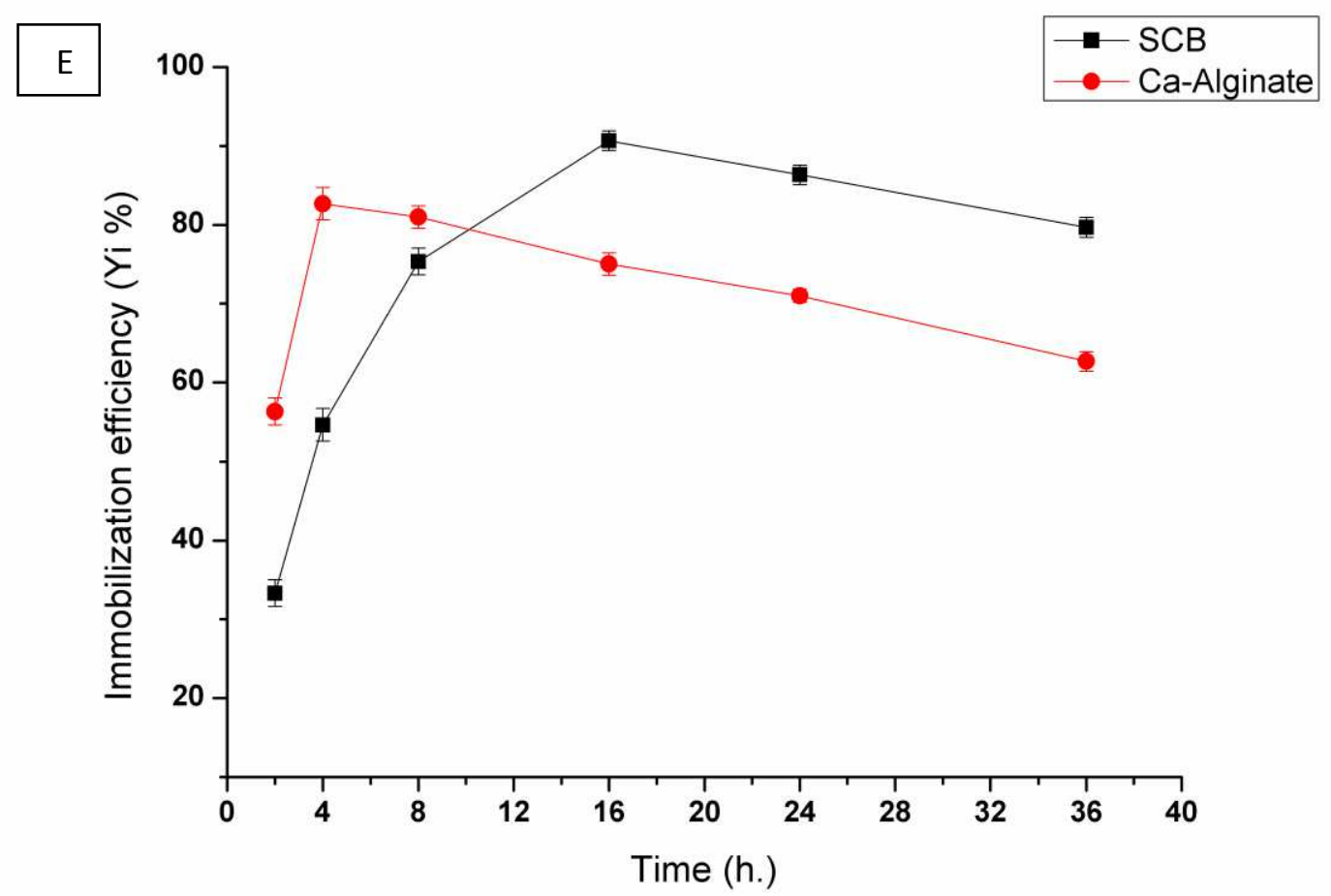

343

344

345 


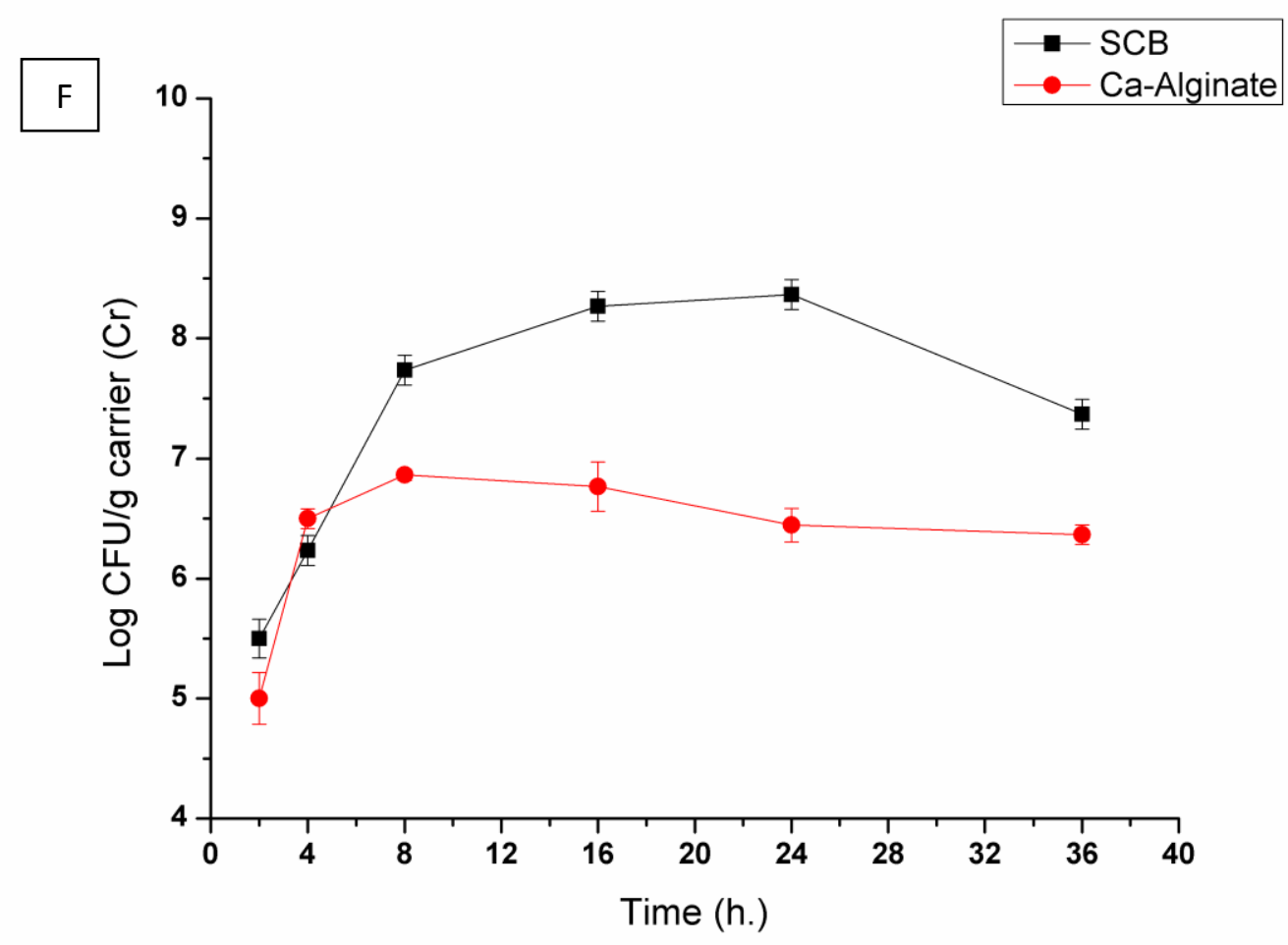

Fig. 1 The free fibrous and nonfibrous biopolymer A and C, respectively. Bacterial cellulose immobilized onto fibrous and nonfibrous biopolymer B and D, respectively. Immobilization efficiency (Yi) (E) and cell retention (Cr) of G. xylinum cells (F) onto $\mathrm{SCB}$ and Ca-alginate as function of time.

\subsection{Effect of matrix size}

Almost of literature reported that use of alginate with $2-4 \%$ being optimally for immobilized cells production (Banerjee and Ghoshal, 2011). Therefore, preparation of different alginate concentrations (1-4\%) was used for evaluating the optimal one. Results depict that the maximum production rate of $\mathrm{BC}$ was showed with $3 \%$ alginate concentration and further concentration caused decreasing gradually in the production rate (data not shown). Apparently, the production rate is found to be decreased at lower alginate concentration (1-2\%) which attributed to rapid ruptured of beads at lower concentrations, while the production rate of $\mathrm{BC}$ observed more reduced at higher alginate concentration (4\%) and that could be related to the difficult diffusivity of the nutrients and bacterial cells through the rigid beads produced at higher concentrations (Banerjee and Ghoshal, 2011). Subsequently, 3\% alginate was utilized for preparing different sizes of beads $(2,3,4$, and $6 \mathrm{~mm})$ to determine its effects on the cellulose production. As illustrated in (Table 2), the rate of cellulose 
yield was increasing with the increase of bead size reaching to its maximum value $(4.8 \pm 0.44 \mathrm{~g} / \mathrm{L})$ at $4 \mathrm{~mm}$ bead diameter and further increase in the alginate beads results in a slightly reducing cellulose yield. However, the bacterial growth was clearly increasing as beads size increased. Although the number of CFU/g alginate beads was increased in larger beads, but the cellulose production rate was decreased and that related to the high difficult diffusion as beads become larger which contributing in lowering the cellulose productivity (Dursun and Tepe, 2005, Banerjee and Ghoshal, 2011). In addition, the main disadvantage of Ca-alginate beads with each size display by the instability and rapid disruption at the end of cultivation period and that may be correlated with the PPW composition. On the other hand, the effect of SCB particle sizes was also established. As mentioned above, SEM profile proved that the immobilized cells are adherence in the alveolate of the stalk cells of the SCB particles. As shown in (Table 1), the cell retention was increased as a SCB particle size was increased. In fact, a larger SCB particle can be carrying more bacterial cells than a smaller one, and that because it has more intact stalk cells (Basak et al., 2014). However, the highest cellulose production $(4.9 \pm 0.18 \mathrm{~g} / \mathrm{L})$ was achieved with smaller SCB particles $(1 \mathrm{mmx} 1 \mathrm{mmx} 1 \mathrm{~mm})$. This phenomenon could be related to the diffusion limitations in larger sizes of SCB particle, since the mass transfer in the interior of this carrier will become more poor and difficult due to the increasing inner mass transfer resistance (Liu et al., 2015). On the other hand, we can also noticed that as SCB become small in size the immobilization efficiency would be increase and the cell retention in the carrier being also increased. Conversely, in case of alginate beads the increase of size could be increase the immobilization efficiency of the carrier and that was directly proportional with the cellulose productivity. Thus, from these results we can conclude that, diffusion limitations could be avoided by using the optimum size of each of matrix. In comparison of SCB and $\mathrm{Ca}$-alginate the obtained results are cleared that the SCB exhibited the higher stability of cells than Ca-alginate which indicated to easily recover from the PPW medium. Since, alginate beads proved to be inefficient to reuse in the PPW culture medium attributed to the rapid disruption of beads in the second cycle which may be due to the deformation or weakening of the alginate matrix in the PPW medium. Therefore, further experiments were desired in order to characterize the nature of the BC-production from each matrix in comparison with free cells and the cellulose producing from the standard medium (HS medium) separately. 
402 Table 2: Effect of carrier size on the BC productivity, Immobilization efficiency, and cell 403 retention

\begin{tabular}{|c|c|c|c|}
\hline Polymer Size & $\begin{array}{c}\text { Cellulose } \\
\text { productivity } \\
(\mathrm{g} / \mathrm{L})\end{array}$ & $\begin{array}{c}\text { Immobilization } \\
\text { efficiency (Yi) } \\
(\%)\end{array}$ & $\begin{array}{l}\text { Bacterial cell } \\
\text { retention }(\mathrm{Cr}) \\
\text { Log } \mathrm{CFU} / \mathrm{g}^{*}\end{array}$ \\
\hline SCB $1 \mathrm{~mm}$ & $4.9 \pm 0.18$ & $92.7 \pm 1.5$ & $7.2 \pm 0.18$ \\
\hline SCB $2.5 \mathrm{~mm}$ & $4.4 \pm 0.52$ & $86.9 \pm 2.3$ & $8.1 \pm 0.21$ \\
\hline SCB 5mm & $4.3 \pm 0.18$ & $76.9 \pm 3.3$ & $6.6 \pm 0.11$ \\
\hline SCB 10mm & $4.1 \pm 0.08$ & $72.1 \pm 1.8$ & $4.9 \pm 0.18$ \\
\hline Alginate $2 \mathrm{~mm}$ & $4.4 \pm 0.22$ & $82.9 \pm 2.2$ & $4.8 \pm 0.12$ \\
\hline Alginate $3 \mathrm{~mm}$ & $4.7 \pm 0.34$ & $86.4 \pm 0.56$ & $4.7 \pm 0.07$ \\
\hline Alginate $4 \mathrm{~mm}$ & $4.8 \pm 0.44$ & $83.1 \pm 1.8$ & $6.1 \pm 0.27$ \\
\hline Alginate $6 \mathrm{~mm}$ & $4.4 \pm 0.12$ & $92.2 \pm 2.2$ & $6.2 \pm 0.14$ \\
\hline Free cells (Control) & $4.4 \pm 0.18$ & - & - \\
\hline HS (Control) & $1.25 \pm 0.11$ & - & - \\
\hline
\end{tabular}

406

407

408

409

410

411

412

413

414

415

416

417

418

419

420

421

422

423

424

\subsection{Characterization of $\mathrm{BC}$-producing from each matrix}

The used instrumental tools are useful in characterization of produced BC which included FTIR, XRD, SEM. The FTIR spectra are clearfield in Fig. (2A). The BCs IR spectra are fit with cellulose (type I). Moreover, the main characteristic bands of cellulose are observed in all produced BCswhere the $\mathrm{OH}$ starching band is observed at around $3400 \mathrm{~cm}^{-1}$ in all produced BCs. Additionally $\mathrm{C}-\mathrm{H}$ starching band is assigned at around $2930 \mathrm{~cm}^{-1}$ in all BCs. Similar, the asymmetric deformation vibration of methyl and methylene is around $1400 \mathrm{~cm}^{-1}$. In addition, the cellulose produced from HS media, PPW media, bagasse immobilized and alginate immobilized are slightly similar. However the crystalinty may be changed from type to other with lowest crystalinty for HS media cellulose and the higher crystalinity is bagasse immobilized cellulose. On the hand, the IR calculations including crtystalinty index (Cr.I.) and MHBS are cleared a significant difference between produced celluloses. The Cr.I. of HS, PPW, alginate, bagasse are 1.1, 1.3, 1.4 and 1.7, respectively. Additionally, the MHBS of HS, PPW, alginate, bagasse are 5.9, 5.4, 5.0 and 4.5, respectively. These results are emphasized that the crystalinity of produced celluloses are different significantly. 


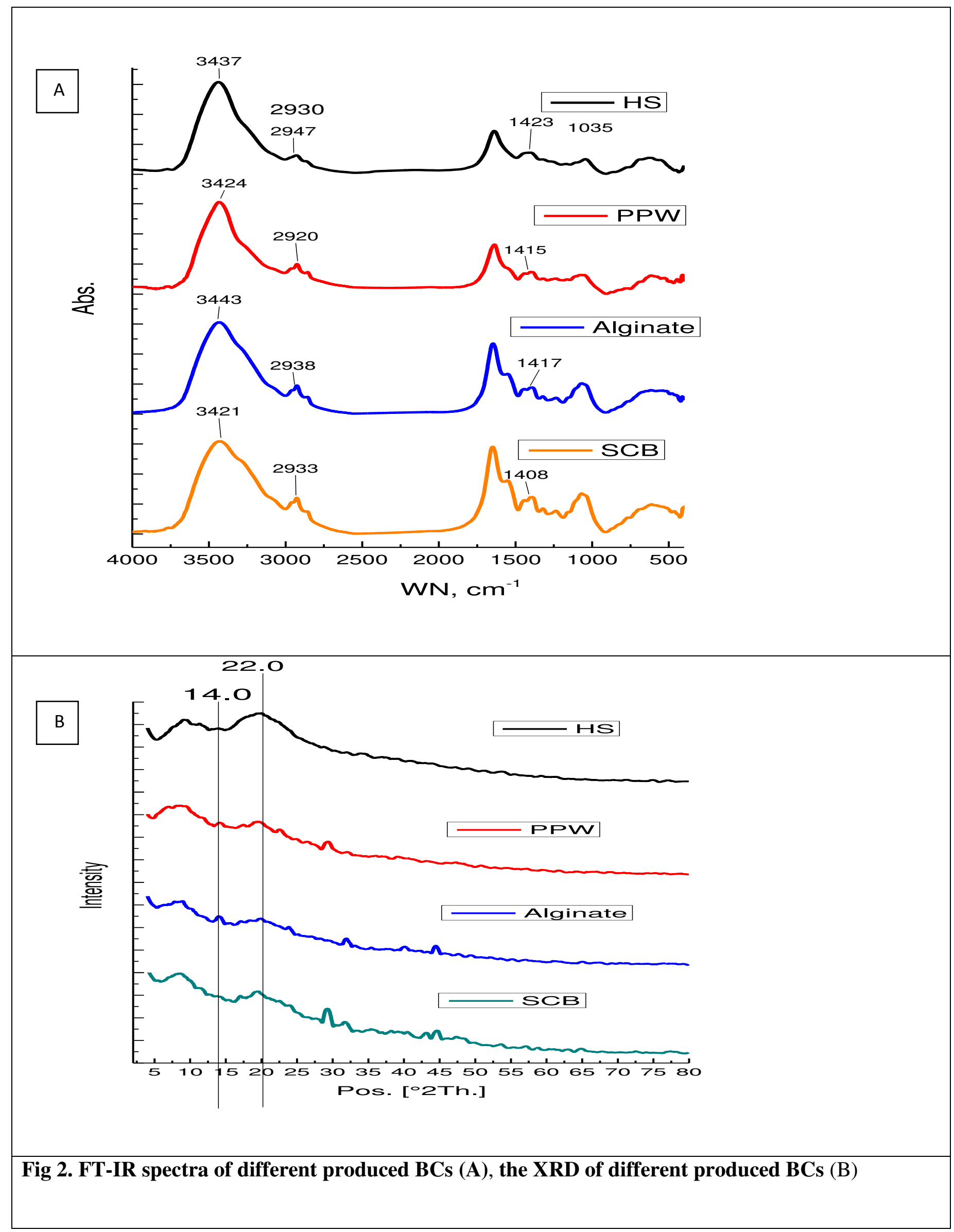


427 characteristic peaks of cellulose at around $22.0^{\circ}$ and $14.0^{\circ}$ are observed in all produced BCs stood for the crystalplane (1-10), and (200), respectively, with significant different. The HS media BC recorded less crystallinitywhichequal 77.5\%. In contrary, The PPW, Alginate immobilized and bagasse immobilized cleared improve in crystallinitywhich recorded 82,84 and 86 for PPW, alginate and bagasse, respectively.

The topography study is carried out on the produced bacterial celluloses show significant differences in topography study in Fig. (3). The HS BC appears as spongy-like this may be referring to low crystallinity as shown in Fig. (3A). The PPW appears as dark spots cellulose with enhance in crystal appearance at Fig. (3B) (Abdelraof et al., 2019a). In addition to, the immobilized result celluloses appear changes in surface morphology. The BC produced from bagasse immobilization observed in Fig. (3C) appears as slid- like cellulose which refers to high crystallinity degree. The BC produced from alginate immobilization in Fig. (3D) appears as cracked surface and this may be referring to the nature of bacteria in present of alginate as immobilization material. Over all the SEM data are emphasized the FT-IR calculations as well as XRD pattern. Accordingly, SCB particles proved to be the efficient carrier for BC immobilization in terms of durability of the matrix and the unique producing-cellulose. Therefore, further optimization of cultural medium conditions using the SCB needs to be studied. 


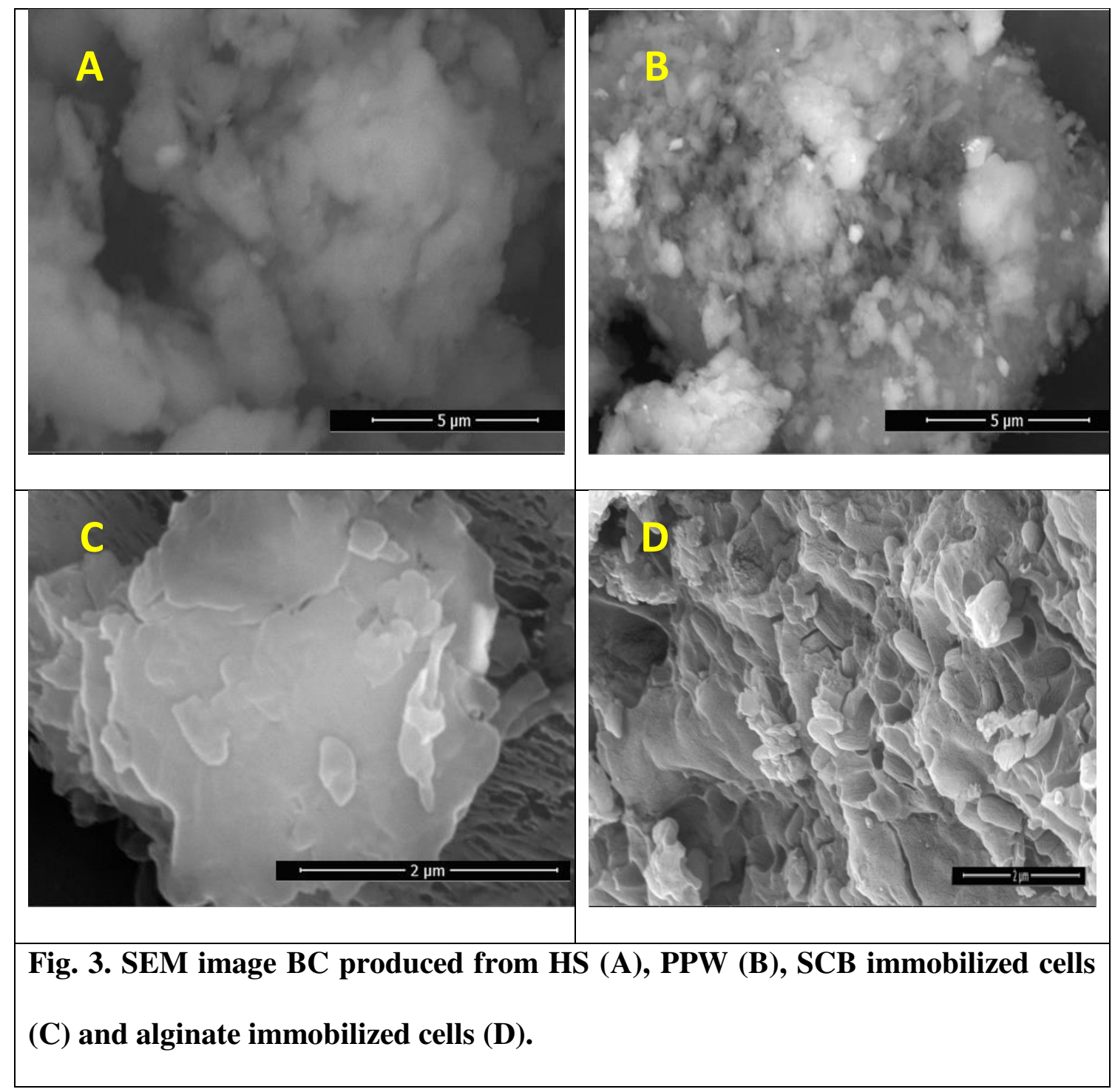

3.5. Optimization of the SCB-immobilized cell system using Plackett-Burman design (PBD)

450 Plackett-Burman design (PBD) has been proposed as one of the statistical approaches

451 to improve the bioprocessing efficiency, since it provides several advantages. Perior 452 to applied PBD, all factors and its levels were firstly selected according to the 453 preliminary studies of one-factor-at-a-time (OFAT) on cellulose production by 454 immobilized G. xylinum (data not shown). In consequence of these results, the 455 independent variables of the cultural conditions that are significantly influence the BC 456 production by SCB immobilized cells were studied by PBD with their respective high 457 and low levels. Results of PBD signified that, there were variations from the BC 458 production which range from 1.6 to $5.2 \mathrm{~g} / \mathrm{L}$ in 21 runs as shown in Table (3). This 459 variation involving the obtained units emphasizes obviously the significance of 
medium optimization to accomplish high BC production by immobilized cells when compared with the $\mathrm{BC}$ production by free cells $(4.4 \mathrm{~g} / \mathrm{L})$ after statistical optimization previously (Abdelraof et al., 2019a). Although the cellulose production efficiencies between the SCB-immobilized cells and the free cells were not significantly different, the cellulose yield produced by the SCB-immobilized cells was slightly higher than those of the free cells. Considering the sugar consumption in this study, the residual sugar concentrations in the supernatant of the immobilized cell culture were also less than those in the fermentation broth of the free cell cultures. In addition, the SCB-immobilized cells displayed a lower CFU number than the free cells in the fermentation broth culture. These findings indicated that the immobilized cell system proved to be higher cellulose productivity than the free cell cultures and that implies to the importance of the SCB carrier to protect the bacterial cells from the external stress conditions which allowing them to perform better than the free ones. Among these variables, the static incubation period and $\mathrm{pH}$ value showed the highest significance through exhibiting its higher positive effect, and then medium volume ratio and sugar concentration in the PPW hydrolysate medium. On contrast, cellulose yield was not influenced by incubation temperature, matrix quantity and spore concentration in the carrier ( $p$ value $>0.05$ ). Overall, the results of contribution of the different variables demonstrate that incubation period has the maximum contribution percent $(42.05 \%)$ followed by $\mathrm{pH}(30.2 \%)$, medium volume ratio (22.5\%) and sugar concentration (5.6\%) and the significant medium components showing $\mathrm{P}$ values $<0.05$ significance level obtained by regression analysis. The rest of the terms have contribution values of less than $1 \%$. Although a very negligible effect of spore concentration was observed on cellulose yield, moderately significant interactive effect of spore concentration and incubation period was noted on cellulose productivity. Insignificant interactive effects were observed for yield and productivity. The optimum levels for the variables obtained by use of stat graphics software were sugar concentration $(10 \% \mathrm{w} / \mathrm{v})$, SCB quantity $(2.0 \% \mathrm{w} / \mathrm{v})$, and spore concentration $(8 \% \mathrm{v} / \mathrm{v})$ at $37^{\circ} \mathrm{C}$ and at $\mathrm{pH} 9.0$ with $25 \mathrm{ml}$ medium volume for 7 days. The analysis of variance (ANOVA) for the experiment design of SCB showed that, the Model F-value of 6.64 implies the model is significant. In such cases A, B, D, E, are significant model terms where "Prob> F" is less than 0.0500. The "Pred R-Squared" of 1.0000 is reasonable agreement with all the "Adj R-Squared" of 1.000. Table (4). 
494 Table 3. Plackett-Burman design (PBD) matrix for BC production from PPW

495 hydrolysate by the SCB or Alginate-immobilized cells of G. xylinum.

\begin{tabular}{|c|c|c|c|c|c|c|c|c|c|c|c|c|}
\hline \multirow[t]{3}{*}{ Runs } & \multirow{3}{*}{$\begin{array}{l}\text { Sugar } \\
\text { conc. } \\
\text { (A) }\end{array}$} & \multirow{3}{*}{$\begin{array}{l}\text { Medium } \\
\text { volume } \\
\text { ratio (B) }\end{array}$} & \multirow{3}{*}{$\begin{array}{l}\text { Spore } \\
\text { conc. } \\
\text { (C) }\end{array}$} & \multirow{3}{*}{$\begin{array}{l}\mathrm{pH} \\
\text { (D) }\end{array}$} & \multirow{3}{*}{$\begin{array}{l}\text { Incubation } \\
\text { time } \\
\text { (E) }\end{array}$} & \multirow{3}{*}{$\begin{array}{l}\text { Incubation } \\
\text { temperature } \\
(\mathrm{F})\end{array}$} & \multirow{3}{*}{$\begin{array}{l}\text { Matrix } \\
\text { quantity } \\
\text { (G) }\end{array}$} & \multicolumn{5}{|c|}{ Response } \\
\hline & & & & & & & & \multicolumn{3}{|c|}{$\mathrm{BC}$ yield $(\mathrm{g} / \mathrm{L})$} & \multirow{2}{*}{$\begin{array}{c}\text { Final } \\
\mathrm{pH}\end{array}$} & \multirow{2}{*}{$\begin{array}{l}\text { Final } \\
\text { sugar } \\
\text { conc. }\end{array}$} \\
\hline & & & & & & & & Actual & Predicated & Residual & & \\
\hline 1 & 7.5 & 37 & 6 & 7.5 & 5.5 & 31 & 3.5 & 2.133 & 2.133 & 0.000 & 6.1 & 2.7 \\
\hline 2 & 5 & 50 & 8 & 9 & 7 & 25 & 2 & 4.833 & 4.640 & 0.193 & 8.5 & 1.8 \\
\hline 3 & 5 & 25 & 8 & 6 & 7 & 25 & 5 & 2.967 & 3.067 & -0.100 & 5.1 & 2.9 \\
\hline 4 & 10 & 50 & 4 & 9 & 7 & 25 & 2 & 4.700 & 5.320 & -0.620 & 8.1 & 3.2 \\
\hline 5 & 5 & 25 & 4 & 6 & 4 & 25 & 2 & 1.767 & 1.647 & 0.120 & 5.7 & 1.7 \\
\hline 6 & 5 & 50 & 8 & 6 & 4 & 25 & 2 & 1.967 & 2.360 & -0.393 & 5.2 & 3.3 \\
\hline 7 & 5 & 25 & 4 & 6 & 7 & 25 & 5 & 3.100 & 3.100 & 0.000 & 4.9 & 1.5 \\
\hline 8 & 10 & 25 & 8 & 6 & 7 & 37 & 5 & 2.900 & 3.427 & -0.527 & 5.2 & 2.9 \\
\hline 9 & 10 & 25 & 4 & 6 & 4 & 37 & 2 & 2.300 & 2.007 & 0.293 & 5.1 & 3.9 \\
\hline 10 & 10 & 50 & 4 & 6 & 7 & 37 & 2 & 3.333 & 3.913 & -0.580 & 5.1 & 2.8 \\
\hline 11 & 5 & 50 & 8 & 6 & 7 & 37 & 2 & 3.967 & 3.233 & 0.733 & 4.9 & 1.4 \\
\hline 12 & 10 & 25 & 8 & 9 & 7 & 37 & 2 & 5.200 & 4.960 & 0.340 & 8.2 & 3.1 \\
\hline 13 & 10 & 50 & 4 & 6 & 4 & 25 & 5 & 3.867 & 3.620 & 0.247 & 5.5 & 4.2 \\
\hline 14 & 5 & 50 & 4 & 9 & 4 & 37 & 5 & 3.600 & 3.597 & 0.003 & 8.7 & 2.2 \\
\hline 15 & 5 & 25 & 8 & 9 & 4 & 37 & 5 & 2.300 & 2.720 & -0.420 & 8.4 & 3.02 \\
\hline 16 & 10 & 25 & 8 & 9 & 4 & 25 & 2 & 2.833 & 3.087 & -0.253 & 8.2 & 2.9 \\
\hline 17 & 5 & 25 & 4 & 9 & 4 & 37 & 2 & 2.233 & 2.467 & -0.233 & 8.0 & 1.6 \\
\hline 18 & 10 & 25 & 4 & 9 & 7 & 25 & 5 & 4.933 & 4.930 & 0.003 & 8.1 & 3.6 \\
\hline 19 & 10 & 50 & 8 & 9 & 4 & 25 & 5 & 5.033 & 4.807 & 0.227 & 8.7 & 2.4 \\
\hline 20 & 10 & 50 & 8 & 6 & 4 & 37 & 5 & 2.800 & 3.000 & -0.200 & 5.4 & 4 \\
\hline 21 & 5 & 50 & 4 & 9 & 7 & 37 & 5 & 4.533 & 4.653 & -0.120 & 8.6 & 1.3 \\
\hline
\end{tabular}

496

497 Table 4. ANOVA of Plackett-Burman experiment

\begin{tabular}{|c|c|c|c|c|c|}
\hline Source & $\begin{array}{l}\text { Sum of } \\
\text { Squares }\end{array}$ & df & $\begin{array}{l}\text { Mean } \\
\text { Square }\end{array}$ & F-Value & \begin{tabular}{|l} 
p-value \\
Prob $>$ F*
\end{tabular} \\
\hline Model & 20.3858 & 8 & 2.54822 & 6.64 & $\begin{array}{c}0.002 \\
\text { Significant }\end{array}$ \\
\hline A-Sugar conc. & 2.1342 & 1 & 2.13422 & 5.56 & 0.036 \\
\hline B-Medium volume ratio & 2.7380 & 1 & 2.73800 & 5.66 & 0.020 \\
\hline C-Spore conc. & 0.0036 & 1 & 0.00356 & 0.01 & 0.925 \\
\hline D-pH & 6.1976 & 1 & 6.19756 & 12.81 & 0.002 \\
\hline E-Incubation time & 6.8056 & 1 & 6.80556 & 14.07 & 0.001 \\
\hline F-Incubation temperature & 0.4302 & 1 & 0.43022 & 0.89 & 0.311 \\
\hline G-Matrix quantity & 0.3920 & 1 & 0.39200 & 0.81 & 0.332 \\
\hline Curvature & 1.6847 & 1 & 1.6847 & 4.39 & 0.048 \\
\hline Lack of Fit & 15.6403 & 13 & 1.2031 & 9.42 & 0.311 \\
\hline Pure Error & 0.6389 & 5 & 0.1278 & & \\
\hline Cor Total & 24.9911 & 20 & & & \\
\hline
\end{tabular}

$498 \quad \mathrm{R}^{2}=0.971$; Adj $\mathrm{R}^{2}=0.955$.df degrees of freedom; *Values of "Prob> $\mathrm{F}$ " less than

4990.0500 indicate model terms are significant. 
culture medium based on the optimization process as described previously. The cycle's number of repeated batch cellulose production by the SCB-immobilized cells and the main fermentation kinetic parameters are summarized in Table 5. As can be seen, reuse of the SCB particles could be exactly carried out for four sequential times without any significant decrease in the operational efficiency of the BC yield. It was observed that the $\mathrm{BC}$ production rate was initially affected at the $7^{\text {th }}$ cycle and that may be related to a limited amount of adsorbed bacterial cells in the carrier. The enhanced cell stability of the immobilized cells as observed in the present study suggests that the SCB carriers may protect the bacterial cells from severe conditions during the fermentation process. The increased cell stability and cell productivity of the immobilized system demonstrated in this study are in agreement with the reports by(Basak et al., 2014, Liu et al., 2015).

\section{Table 5. Reusability of the immobilized G. xylinum}

\begin{tabular}{|c|c|c|c|c|}
\hline Batch No. & $\begin{array}{c}\text { Operational } \\
\text { efficiency }(\%)\end{array}$ & $\begin{array}{c}\text { BC productivity } \\
\text { rate (g/L. h) }\end{array}$ & $\begin{array}{c}\text { BC production } \\
\text { yield (\%) }\end{array}$ & $\begin{array}{c}\text { Substrate conversion } \\
\text { ratio \% }\end{array}$ \\
\hline 1 & $100 \pm 0.05$ & 0.0433 & $47.7 \pm 0.5$ & $49.5 \pm 0.8$ \\
\hline 2 & $100 \pm 0.12$ & 0.0435 & $42.6 \pm 1.1$ & $55.4 \pm 1.5$ \\
\hline 3 & $100 \pm 0.11$ & 0.0435 & $46.8 \pm 1.8$ & $50.4 \pm 2.2$ \\
\hline 4 & $100 \pm 0.07$ & 0.0432 & $52.5 \pm 2.2$ & $45 \pm 0.9$ \\
\hline 5 & $100 \pm 0.02$ & 0.0433 & $55.9 \pm 0.8$ & $42.2 \pm 1.4$ \\
\hline 6 & $90.3 \pm 1.5$ & 0.0391 & $55.2 \pm 1.5$ & $38.6 \pm 0.6$ \\
\hline 7 & $78.8 \pm 2.1$ & 0.0341 & $51.8 \pm 1.8$ & $35.9 \pm 0.8$ \\
\hline 8 & $61.5 \pm 1.7$ & 0.0266 & $44.4 \pm 0.5$ & $32.7 \pm 1.3$ \\
\hline 9 & $34.6 \pm 2.3$ & 0.015 & $33.9 \pm 1.9$ & $24 \pm 0.9$ \\
\hline 10 & $15.3 \pm 1.1$ & 0.003 & $14.8 \pm 2.1$ & $12.2 \pm 2.2$ \\
\hline Free cells on PPW & - & 0.0401 & $32.1 \pm 1.4$ & $73.7 \pm 0.8$ \\
\hline HS medium & - & 0.022 & $14.3 \pm 1.6$ & $55.5 \pm 0.4$ \\
\hline
\end{tabular}

554 With respect to the kinetic studies, the SCB-immobilized cells exhibited slightly 555 higher cellulose productivity rate $(0.043 \mathrm{~g} / \mathrm{L} . \mathrm{h})$ through five repeated batch 
fermentation than the free cells $(0.0401 \mathrm{~g} / \mathrm{L} . \mathrm{h})$. After that, the cellulose productivity was starting reduced and this might be due to the fact that the immobilized cells was reduced in the carrier and that was clearly appeared in the substrate conversion rate which decreased with $10 \%$. To deeply understand these changes, it should be noted that the utilization of sugars by the SCB-immobilized cells was not restricted with the carrier system, suggested that the diffusion of the substrates was not prevented by the carriers, which were highly porous and thus, facilitated the mass transfer of the system. However, the decreasing in the loaded bacterial cells under repeated batch condition contributes in the lowering substrate conversion rate which led to reducing in the BC production efficiency. In addition, an increase in the number of viable cells adsorbed on the inner surfaces and in the micro-porous structure of the matrix suggesting that high sugar concentrations in the fermentation broth had no effect on the bacterial growth. We propose, from these findings, that the regeneration and protection of immobilized cells by the SCB are the main factors that work synergistically to prevent cell activity.

Storage stability of SCB immobilized Glucanobacter xylinum at $4^{\circ} \mathrm{C}$ and room temperature with long term was investigated through 28 day. Viability of bacterial cells were expressed as remaining total number of Log CFU per gram of SCB, along with determined the operational efficiency of BC yield on every $7^{\text {th }}$ day as a function time. Results are shown in Fig. (5), clearly indicate that at $4^{\circ} \mathrm{C}$ the immobilized cells was still retain in the SCB with $44.3 \%$ up to the full period with high operational efficiency reached to 21 days. However the storage stability of SCB at room temperature was not suitable to retain the cells during 28 days, only a small amount of immobilized cells was remained in the carrier $(7.7 \%)$ correlated with sharply reduced in the $\mathrm{BC}$ production. This phenomenon may be due to the change in the storage temperature which increases the mass transfer barrier in the SCB at the room temperature caused the bacterial cells to die during the long term storage. This study shows reasonable effectiveness for practical use of the SCB carrier which capable to retaining the immobilized cells without any expensive storage conditions. 

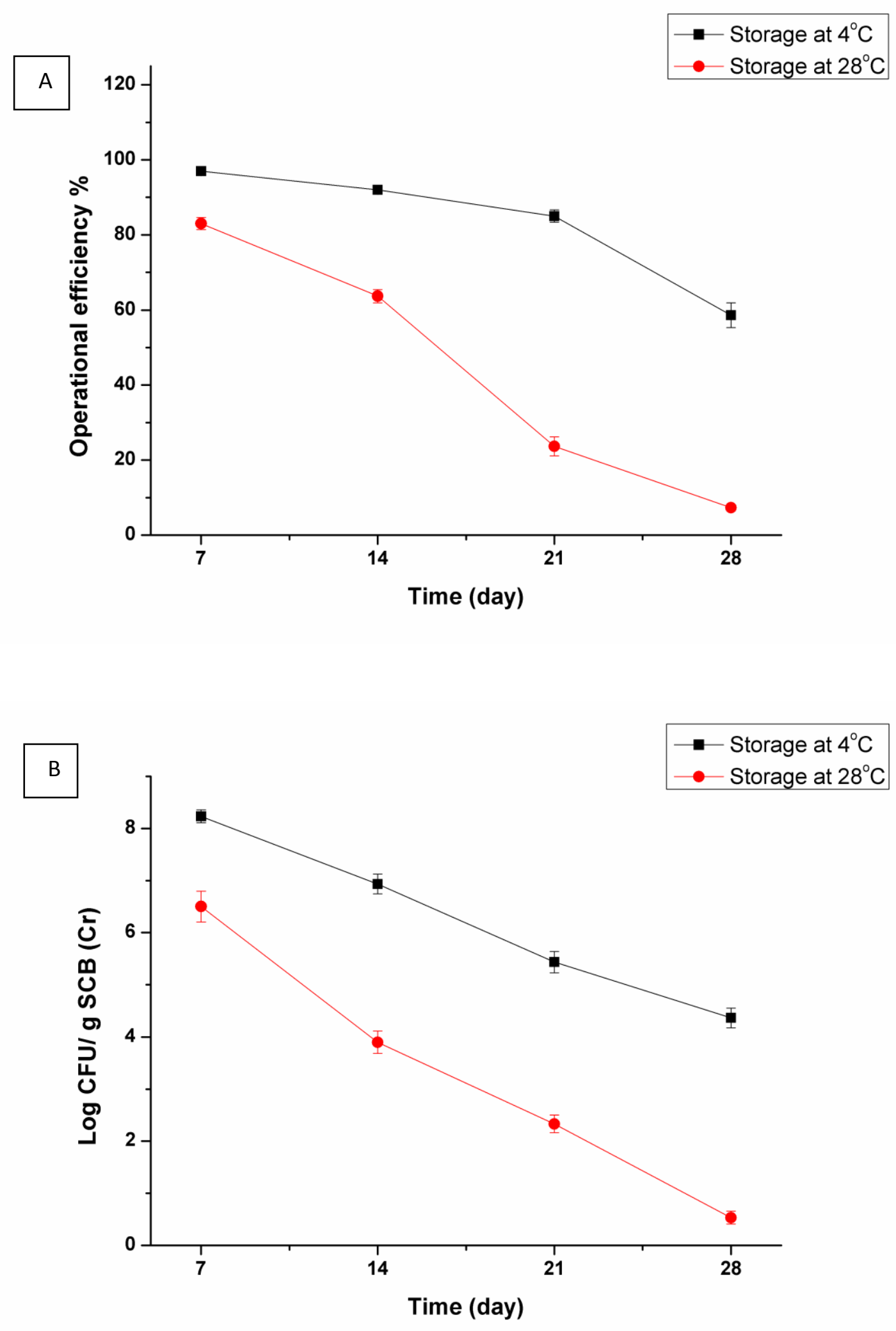

590 Fig. 5 Storage stability of the SCB-immobilized cells: Immobilization efficiency

591 (Yi) (A) and cell retention (Cr) of G. xylinum cells (B) during 28 days 


\section{Conclusion}

Utilization of waste from the food industry as raw materials for both immobilized the bacterial cells and prepared the culture medium promotes economic advantages because they reduce environmental pollution and stimulate new research for science sustainability. The observed study was carried out to produce bacterial cellulose via immobilization onto fibrous and non fibrous bio-polymers. The foregoing results justify the applicability of SCB as carrier matrix for immobilization of $\mathrm{BC}$ in biosynthesis of cellulose from Potato Peel Waste hydrolysate culture medium. Reused immobilized biomass indicated sustained cellulose production even after 6 cycles. The instrumental analysis of $\mathrm{BC}$ produced from fibrous biopolymer showed excellent characters with high crystal structure and homogenous network as illustrated from SEM topography. These results demonstrate the feasibility of the proposed immobilization system to be used in future industrial BC production from low cost raw materials.

\section{Abbreviations}

BC: Bacterial Cellulose, SCB: Sugar Cane Bagasse, PPW: Potato Peel Waste, PVA: Poly Vinyl Alcohol, PBD: Placket-Burman Design, ATCC: American Type Culture Collection, DNS: Di-Nitro-Salicylic acid, CFU: Colony Forming Unit, SEM: Scanning Electron Microscope, XRD: X-Ray Diffractions, FT-IR: Fourier transform infrared, OFAT: One-Factor-At-A-Time.

\section{Declaration}

\section{Ethics approval and consent to participate}

Not applicable

\section{Acknowledgment}

The authors acknowledge the National Research Center, Egypt for financial support. Since the research experiments was completely sponsored by Department of Microbial Chemistry Dep., and Paper and Cellulose Dep., National Research Centre, Giza, Egypt

\section{Authors' contributions}


624 MA carries out the immobilization process of the bacterial cells onto biopolymers,

625 statistical optimization of the BC production and applies the reusability and storage 626 stability test. MH makes the characterization of the cellulose-producing from each of 627 system by FT-IR, XRD and SEM. MA, MH, and HE wrote the manuscript and 628 participated in the data discussion, data analyses, and drafting of the manuscript. All 629 authors have read and approved the manuscript.

630

631 Funding

632 Not applicable

633

\section{Availability of data and materials}

635

Data will be made available upon request.

636

637

\section{Consent for publication}

638

Not applicable.

639

640

Competing interests

641

The authors declare that they have no conflict of interests regarding the publication of

642 this manuscript.

643

644

Author Information

645

1 Mohamed Abdelraof Researcher at Microbial Chemistry Department, National

646 Research Centre, 12622, Dokki, Cairo, Egypt.

2 Houssni El -Saied Professor at Cellulose and Paper Department, National Research Centre, 12622, Dokki, Cairo, Egypt.

6492 Mohamed S. Hasanin Researcher at Cellulose and Paper Department, National

650 Research Centre, 12622, Dokki, Cairo, Egypt.

651

652

References

653

Abdelraof, M., M. M. A. Elsoud, M. H. Selim, and A. A. Hassabo. 2020a. I-arginine 24:101538. 
Abdelraof, M., M. S. Hasanin, and H. El-Saied. 2019a. Ecofriendly green conversion of potato peel wastes to high productivity bacterial cellulose. Carbohydrate polymers 211:75-83. Abdelraof, M., M. S. Hasanin, M. M. Farag, and H. Y. Ahmed. 2019b. Green synthesis of bacterial cellulose/bioactive glass nanocomposites: Effect of glass nanoparticles on cellulose yield, biocompatibility and antimicrobial activity. International journal of biological macromolecules 138:975-985.

Abdelraof, M., S. Ibrahim, M. A. Selim, and M. Hasanin. 2020b. Immobilization of Lmethionine $\gamma$-lyase on different cellulosicmaterialsand its potential application in greenselective synthesis of volatile sulfur compounds. Journal of Environmental Chemical Engineering:103870.

Abdelraof, M., M. H. Selim, M. M. A. Elsoud, and M. M. Ali. 2019c. Statistically optimized production of extracellular I-methionine $\gamma$-lyase by Streptomyces Sp. DMMMH60 and evaluation of purified enzyme in sub-culturing cell lines. Biocatalysis and agricultural biotechnology 18:101074.

Banerjee, A. and A. K. Ghoshal. 2011. Phenol degradation performance by isolated Bacillus cereus immobilized in alginate. International Biodeterioration \& Biodegradation 65(7):10521060.

Basak, B., B. Bhunia, and A. Dey. 2014. Studies on the potential use of sugarcane bagasse as carrier matrix for immobilization of Candida tropicalis PHB5 for phenol biodegradation. International Biodeterioration \& Biodegradation 93:107-117.

Bilgi, E., E. Bayir, A. Sendemir-Urkmez, and E. E. Hames. 2016. Optimization of bacterial cellulose production by Gluconacetobacter xylinus using carob and haricot bean. International journal of biological macromolecules 90:2-10.

Chen, L., F. Hong, X.-x. Yang, and S.-f. Han. 2013. Biotransformation of wheat straw to bacterial cellulose and its mechanism. Bioresource technology 135:464-468.

Chen, S. and Y. Huang. 2015. Bacterial cellulose nanofibers decorated with phthalocyanine: Preparation, characterization and dye removal performance. Materials Letters 142:235-237. Cheng, K.-C., J. M. Catchmark, and A. Demirci. 2009. Enhanced production of bacterial cellulose by using a biofilm reactor and its material property analysis. Journal of biological engineering 3(1):12.

Cheng, Z., R. Yang, and X. Liu. 2017. Production of bacterial cellulose by Acetobacter xylinum through utilizing acetic acid hydrolysate of bagasse as low-cost carbon source. BioResources 12(1):1190-1200.

Dursun, A. Y. and O. Tepe. 2005. Internal mass transfer effect on biodegradation of phenol by Ca-alginate immobilized Ralstonia eutropha. Journal of hazardous materials 126(1-3):105111.

Dzionek, A., D. Wojcieszyńska, and U. Guzik. 2016. Natural carriers in bioremediation: A review. Electronic Journal of Biotechnology 19(5):28-36.

Hasanin, M. S. and S. A. Al Kiey. 2020. Environmentally benign corrosion inhibitors based on cellulose niacin nano-composite for corrosion of copper in sodium chloride solutions. International Journal of Biological Macromolecules.

Hasanin, M. S., O. M. Darwesh, I. A. Matter, and H. El-Saied. 2019. Isolation and characterization of non-cellulolytic Aspergillus flavus EGYPTA5 exhibiting selective ligninolytic potential. Biocatalysis and agricultural biotechnology 17:160-167.

Hasanin, M. S., A. M. Mostafa, E. A. Mwafy, and O. M. Darwesh. 2018. Eco-friendly cellulose nano fibers via first reported Egyptian Humicola fuscoatra Egyptia X4: Isolation and characterization. Environmental nanotechnology, monitoring \& management 10:409-418. Hong, F., X. Guo, S. Zhang, S.-f. Han, G. Yang, and L. J. Jönsson. 2012. Bacterial cellulose production from cotton-based waste textiles: enzymatic saccharification enhanced by ionic liquid pretreatment. Bioresource technology 104:503-508. 

S. Bielecki, and Z. Pasieka. 2013. Modified bacterial cellulose tubes for regeneration of damaged peripheral nerves. Archives of medical science: AMS 9(3):527. Lin, D., P. Lopez-Sanchez, R. Li, and Z. Li. 2014. Production of bacterial cellulose by Gluconacetobacter hansenii CGMCC 3917 using only waste beer yeast as nutrient source. Bioresource Technology 151:113-119. Liu, J., S. Chen, J. Ding, Y. Xiao, H. Han, and G. Zhong. 2015. Sugarcane bagasse as support for immobilization of Bacillus pumilus $\mathrm{HZ}-2$ and its use in bioremediation of mesotrionecontaminated soils. Applied microbiology and biotechnology 99(24):10839-10851. Lu, H., Q. Jia, L. Chen, and L. Zhang. 2016. Effect of organic acids on bacterial cellulose produced by Acetobacter xylinum. Journal of Microbiology and Biotechnology 5(2):1-6. Miller, G. L. 1959. Use of dinitrosalicylic acid reagent for determination of reducing sugar. Analytical chemistry 31(3):426-428.

Moreno Rivas, S. C., R. I. Armenta Corral, M. d. C. Frasquillo Félix, A. R. Islas Rubio, L. Vázquez Moreno, and G. Ramos-Clamont Montfort. 2019. Removal of Cadmium from Aqueous Solutions by Saccharomyces cerevisiae-Alginate System. Materials 12(24):4128. Morgan, J. L., J. T. McNamara, and J. Zimmer. 2014. Mechanism of activation of bacterial cellulose synthase by cyclic di-GMP. Nature structural \& molecular biology 21(5):489-496. Nuanpeng, S., S. Thanonkeo, P. Klanrit, and P. Thanonkeo. 2018. Ethanol production from sweet sorghum by Saccharomyces cerevisiae DBKKUY-53 immobilized on alginate-loofah matrices. brazilian journal of microbiology 49:140-150.

Santos, D. T., B. F. Sarrouh, J. D. Rivaldi, A. Converti, and S. S. Silva. 2008. Use of sugarcane bagasse as biomaterial for cell immobilization for xylitol production. Journal of Food Engineering 86(4):542-548.

Srivastava, D. and C. M. Waters. 2012. A tangled web: regulatory connections between quorum sensing and cyclic di-GMP. Journal of bacteriology 194(17):4485-4493.

Stepanov, N. and E. Efremenko. 2018. "Deceived" concentrated immobilized cells as biocatalyst for intensive bacterial cellulose production from various sources. Catalysts 8(1):33.

Watanabe, K., M. Tabuchi, Y. Morinaga, and F. Yoshinaga. 1998. Structural features and properties of bacterial cellulose produced in agitated culture. Cellulose 5(3):187-200. Yu, J., X. Zhang, and T. Tan. 2007. An novel immobilization method of Saccharomyces cerevisiae to sorghum bagasse for ethanol production. Journal of biotechnology 129(3):415740420. 


\section{Figures}
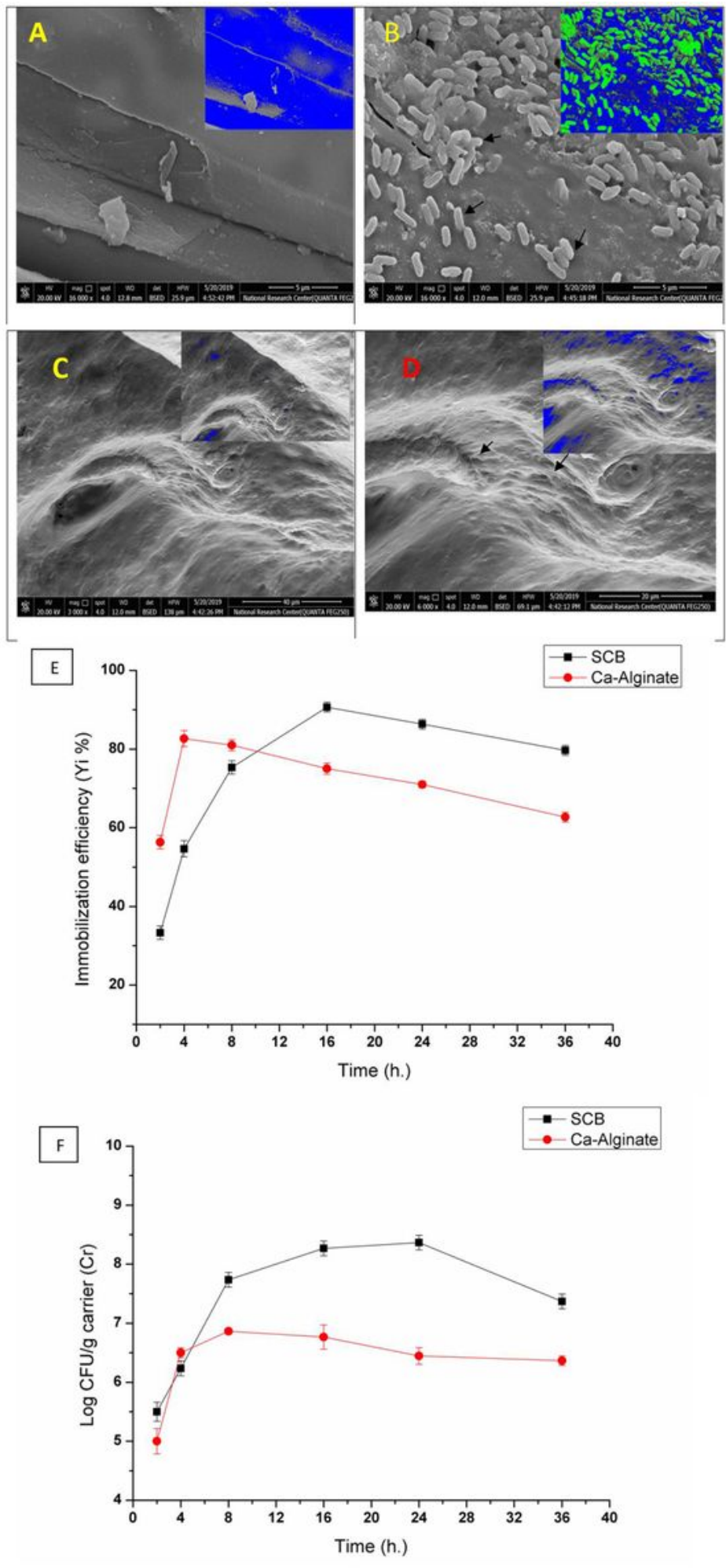

\section{Figure 1}

The free fibrous and nonfibrous biopolymer $A$ and $C$, respectively. Bacterial cellulose immobilized onto fibrous and nonfibrous biopolymer $B$ and $D$, respectively. Immobilization efficiency ( $Y i)(E)$ and cell retention ( $\mathrm{Cr}$ ) of $\mathrm{G}$. xylinum cells $(\mathrm{F})$ onto SCB and $\mathrm{Ca}$-alginate as function of time. 


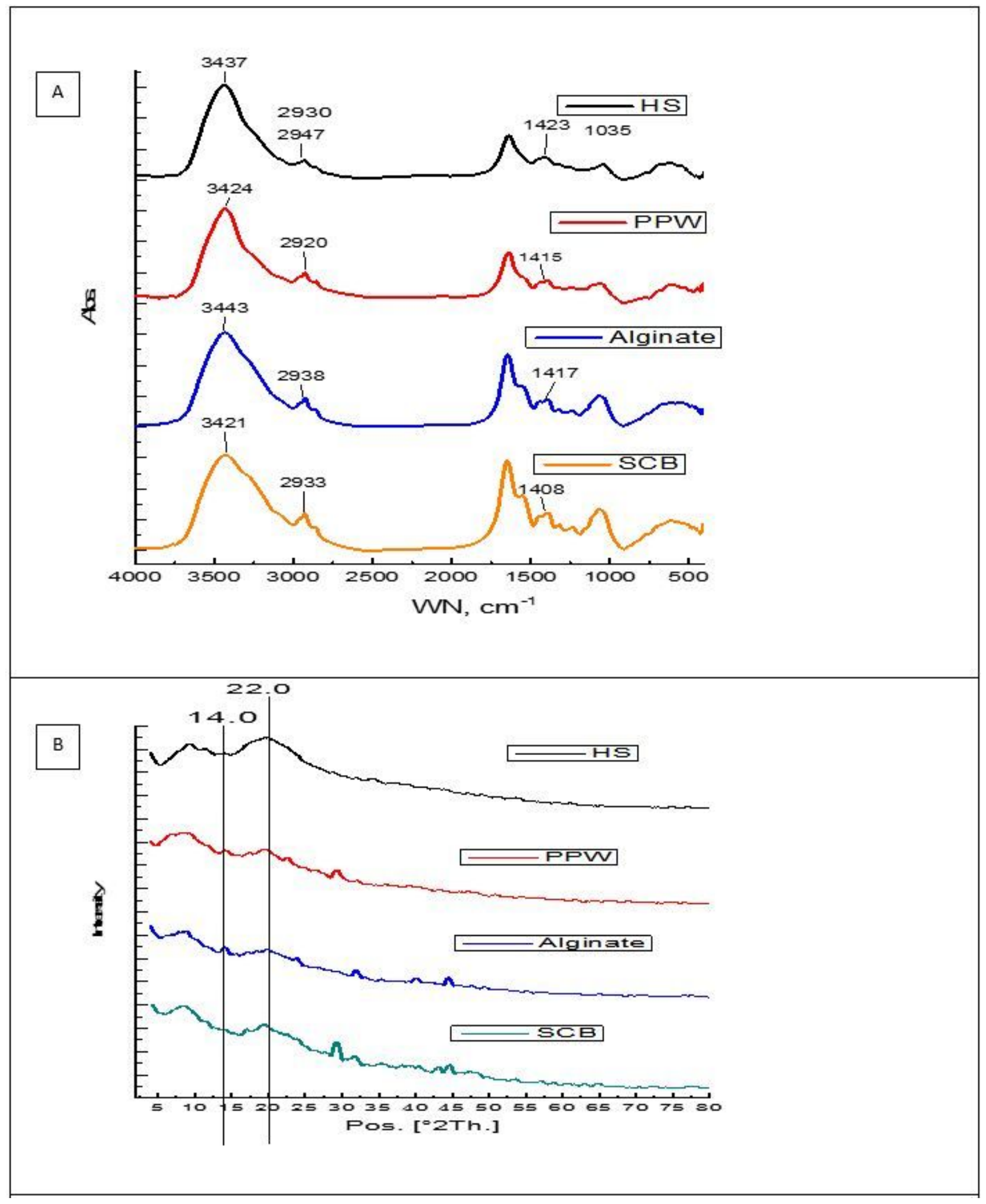

Figure 2

FT-IR spectra of different produced BCs (A), the XRD of different produced BCs (B) 


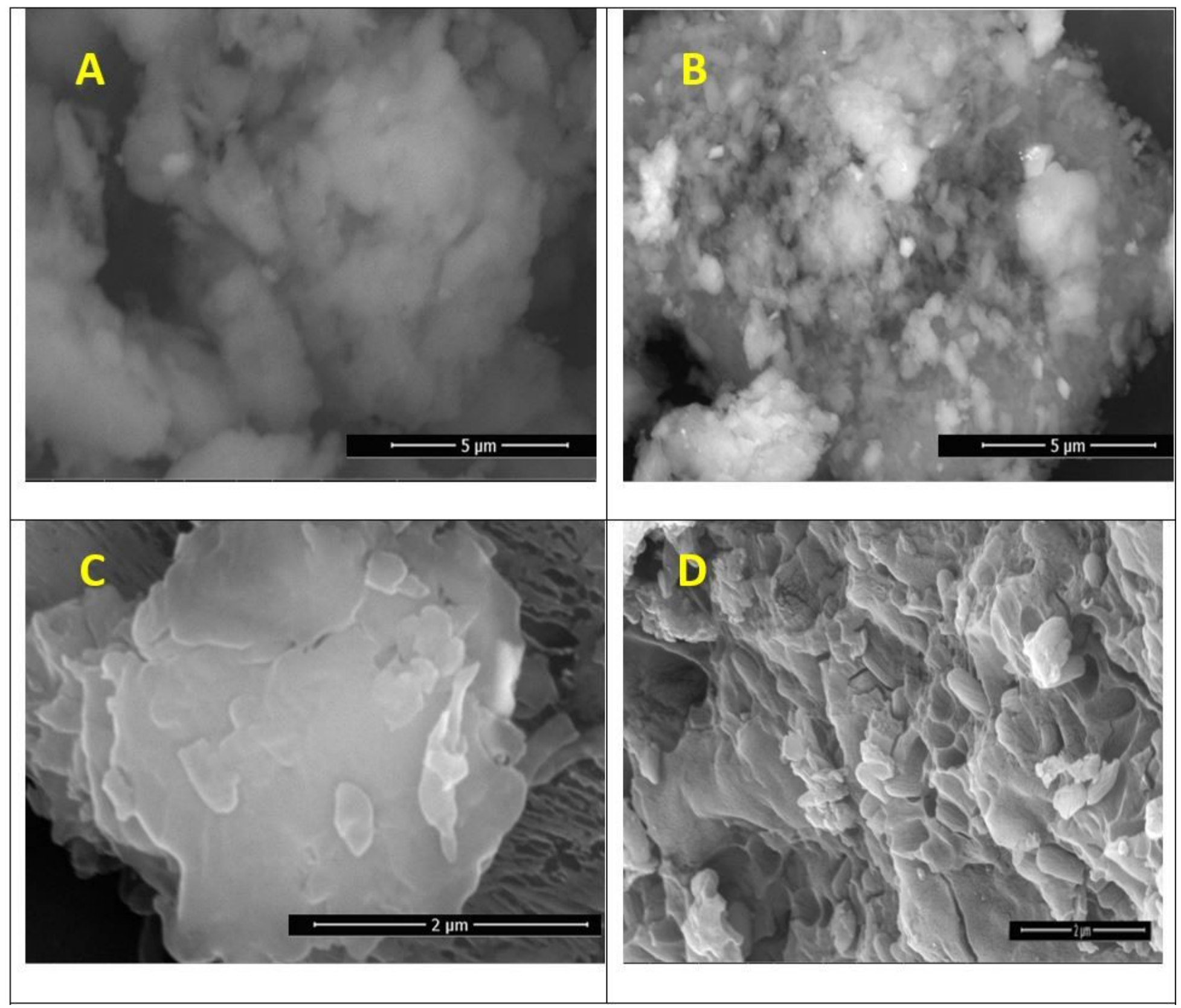

Figure 3

SEM image BC produced from HS (A), PPW (B), SCB immobilized cells (C) and alginate immobilized cells (D). 


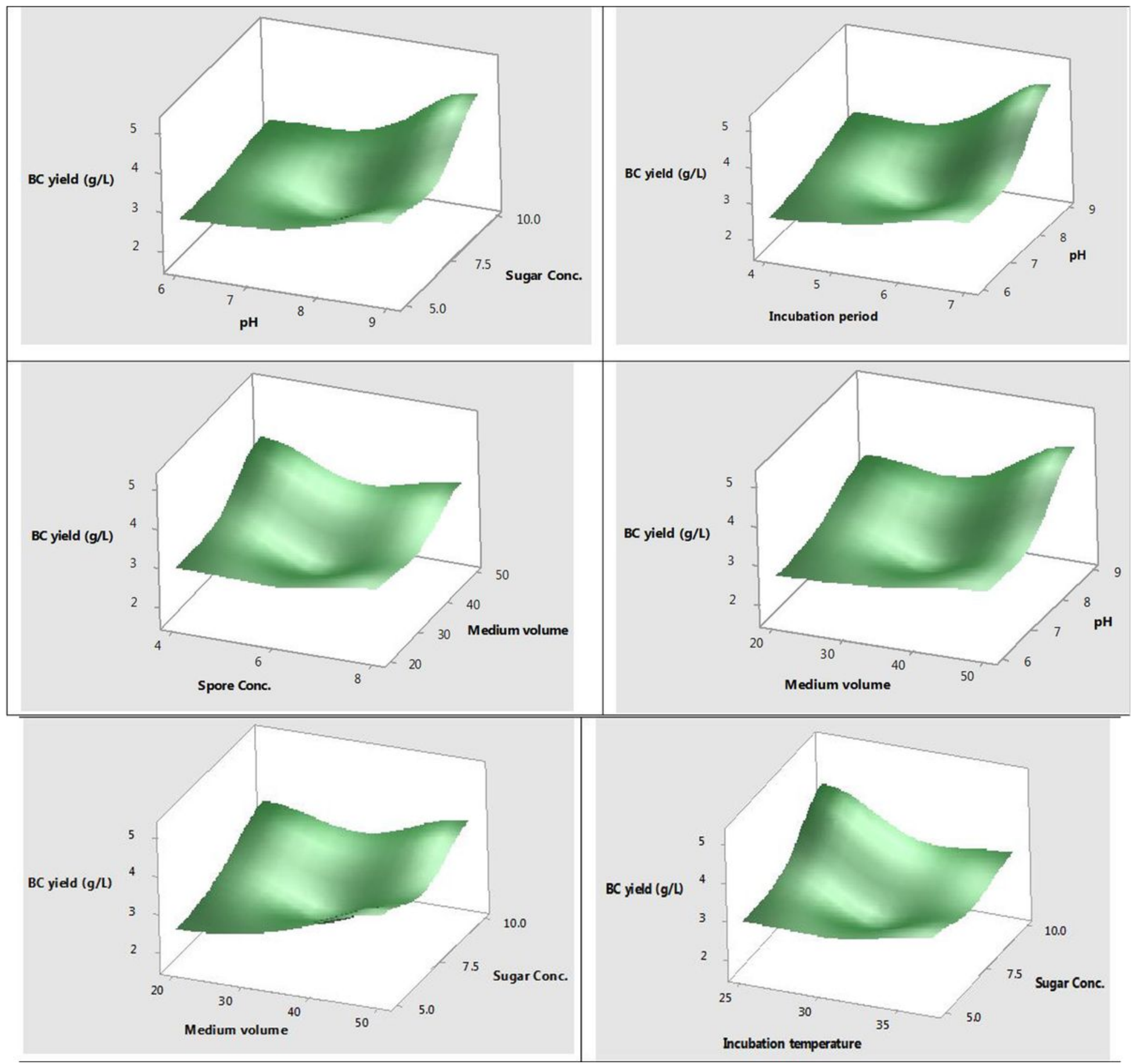

Figure 4

Three dimensional (3D) response surface plots-generated by Minitab-17 software

\section{Supplementary Files}

This is a list of supplementary files associated with this preprint. Click to download.

- GraphicalAbstract.docx 